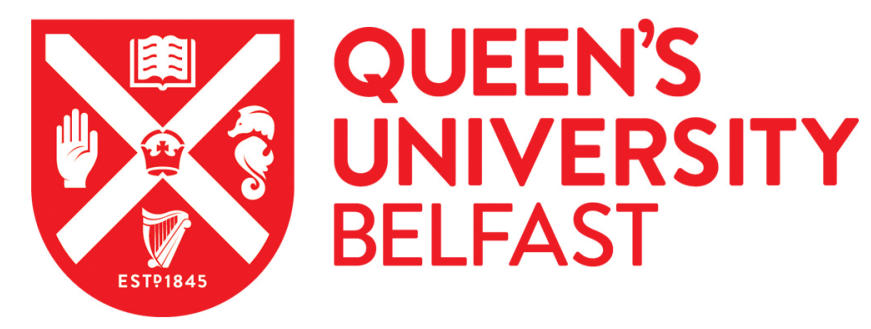

\title{
Highly efficient synthesis of alkyl levulinates from $\alpha$-angelica lactone, catalysed with Lewis acidic trifloaluminate ionic liquids supported on carbon nanotubes
}

Latos, P., Szelwicka, A., Boncel, S., Jurczyk, S., Swadzba-Kwasny, M., \& Chrobok, A. (2019). Highly efficient synthesis of alkyl levulinates from $\alpha$-angelica lactone, catalysed with Lewis acidic trifloaluminate ionic liquids supported on carbon nanotubes. ACS Sustainable Chemistry \& Engineering, 7(5), 5184-5191.

https://doi.org/10.1021/acssuschemeng.8b06066

\section{Published in:}

ACS Sustainable Chemistry \& Engineering

\section{Document Version:}

Peer reviewed version

Queen's University Belfast - Research Portal:

Link to publication record in Queen's University Belfast Research Portal

\section{Publisher rights}

(C) 2019 American Chemical Society.

This work is made available online in accordance with the publisher's policies. Please refer to any applicable terms of use of the publisher.

\section{General rights}

Copyright for the publications made accessible via the Queen's University Belfast Research Portal is retained by the author(s) and / or other copyright owners and it is a condition of accessing these publications that users recognise and abide by the legal requirements associated with these rights.

Take down policy

The Research Portal is Queen's institutional repository that provides access to Queen's research output. Every effort has been made to ensure that content in the Research Portal does not infringe any person's rights, or applicable UK laws. If you discover content in the

Research Portal that you believe breaches copyright or violates any law, please contact openaccess@qub.ac.uk. 


\title{
Highly efficient synthesis of alkyl levulinates from $\alpha-$
}

\author{
angelica lactone, catalysed with Lewis acidic
}

\section{trifloaluminate ionic liquids supported on carbon}

\section{nanotubes}

Piotr Latos, ${ }^{1}$ Anna Szelwicka, ${ }^{1}$ Stawomir Boncel, ${ }^{2}$ Sebastian Jurczyk, ${ }^{3}$ Matgorzata Swadźba-Kwaśny, ${ }^{4}$ Anna Chrobok ${ }^{1 *}$

${ }^{1}$ Department of Organic Chemical Technology and Petrochemistry, Silesian University of Technology, Krzywoustego 4, 44-100 Gliwice, Poland, e-mail: Anna.Chrobok@polsl.pl

${ }^{2}$ Department of Organic Chemistry, Bioorganic Chemistry and Biotechnology, Silesian University of Technology, Krzywoustego 6, 44-100 Gliwice, Poland

${ }^{3}$ Institute for Engineering of Polymer Materials and Dyes, M. Skłodowskiej-Curie 55, 87-100 Toruń, Poland

${ }^{4}$ QUILL Research Centre, School of Chemistry and Chemical Engineering, Queen's University Belfast, David Keir Building, Stranmillis road, Belfast, BT9 5AG, UK

KEYWORDS: Ionic liquids, carbon nanotubes, Lewis acids, levulinic acid esters, angelica lactone, supported ionic liquid phase, trifloaluminate 


\begin{abstract}
Levulinic acid esters (LAEs) were synthesised from $\alpha$-angelica lactone and alcohols, in a reaction catalysed by a new family of chloride-free Lewis acidic ionic liquids, containing trifloaluminate anions, $\left[\mathrm{Al}(\mathrm{OTf})_{3+n}\right]^{n-}$. Changing the catalyst from poorly soluble $\mathrm{Al}(\mathrm{OTf})_{3}$ (used as suspension) to fully homogenous trifloaluminate ionic liquids resulted in shorter reaction times required for full $\alpha$-AL conversion (60 $\mathrm{min}$ at $60{ }^{\circ} \mathrm{C}$ for $0.1 \mathrm{~mol} \%$ catalyst loading), and unprecedented selectivities to LAEs, reaching $>99 \%$. Supporting the trifloaluminate ionic liquid on multi-walled carbon nanotubes gave an easily-recyclable system, with no leaching observed over 6 cycles. Mechanistic considerations suggest that the propensity of $\mathrm{Al}(\mathrm{OTf})_{3}$ to undergo very slow hydrolysis results in the correct balance of Brønsted and Lewis acidic sites in the system, inhibiting by-product formation.
\end{abstract}

\title{
Introduction
}

Levulinic acid (LA) and levulinic acid esters (LAEs) are important biomass-derived platform chemicals, which can be used for the synthesis of pharmaceuticals, flavours and fragrances, agrochemicals, resins and coatings, plasticizers, solvents, fuel additives, and biofuels production. ${ }^{1}$ LA can be produced from renewable resources such as sugars, lignocellulosic biomass and waste materials. ${ }^{1}$ The corresponding esters are most commonly synthesised by direct esterification of LA in the presence of heteropolyacidsbased heterogeneous catalysts ${ }^{2}$ or sulfonated materials, ${ }^{3}$ but these syntheses suffer from typical issues concerning equilibrium esterification reactions, that is challenges with water removal and the requirement for excess alcohol. Alternatively, LAEs can be produced directly from polysaccharides, but the process is inefficient, with long reaction times at high temperatures $\left(20 \mathrm{~h}, 175^{\circ} \mathrm{C}\right)$ giving medium yields of the product (e.g. $56 \%$ of methyl levulinate) ${ }^{4}$ A slightly more efficient is a multi-step transformation of monosaccharides (e.g. fructose) via 5-hydroxymethylfurfural to LA, and subsequent esterification. This process, catalysed by solid acidic catalysts such as sulfonated carbon nanotubes, ${ }^{5}$ affords LAEs in 
relatively high yields (up to $84 \%$ of ethyl levulinate) and under slightly more moderate conditions ( $24 \mathrm{~h}$, $\left.120^{\circ} \mathrm{C}\right) .{ }^{5,6}$ Finally, furfuryl alcohol can also be transformed to LAEs at $120-140{ }^{\circ} \mathrm{C}$, over acidic catalysts including sulfonated materials, ${ }^{7}$ acidic ionic liquids ${ }^{8}$ or acid functionalized organosilica nanotubes. ${ }^{9,10}$

Recently, an interesting alternative route to access LAEs from LA has been proposed. Intramolecular condensation of LA with a subsequent dehydration leads to the formation of $\alpha$-angelica lactone (5-methyl2(3H)-furanone, $\alpha-\mathrm{AL})$, which make useful building block in its own right. $\alpha-\mathrm{AL}$ can be converted to LAEs in a one-pot reaction, which overcomes the equilibrium issues of conventional esterification (Scheme 1). ${ }^{11,12,13}$ Using Amberlyst $36^{12}$ or a range of choline-exchanged heteropolyacids ${ }^{13}$ as catalysts led to the formation of LAE with $79-94 \%$ selectivity and full conversion of $\alpha$-angelica, at $75{ }^{\circ} \mathrm{C}$; byproducts included the unreacted pseudo- $n$-alkyl levulinate (Scheme 1) and LA. A heteropolyacid catalyst was identified that could be reused 5 times without significant activity loss, ${ }^{13}$ however, this recyclable system exhibited lower selectivity. Clearly, the $\alpha$-AL-to-LAEs route is a promising one, but an efficient, selective and recyclable catalyst is yet to be found.

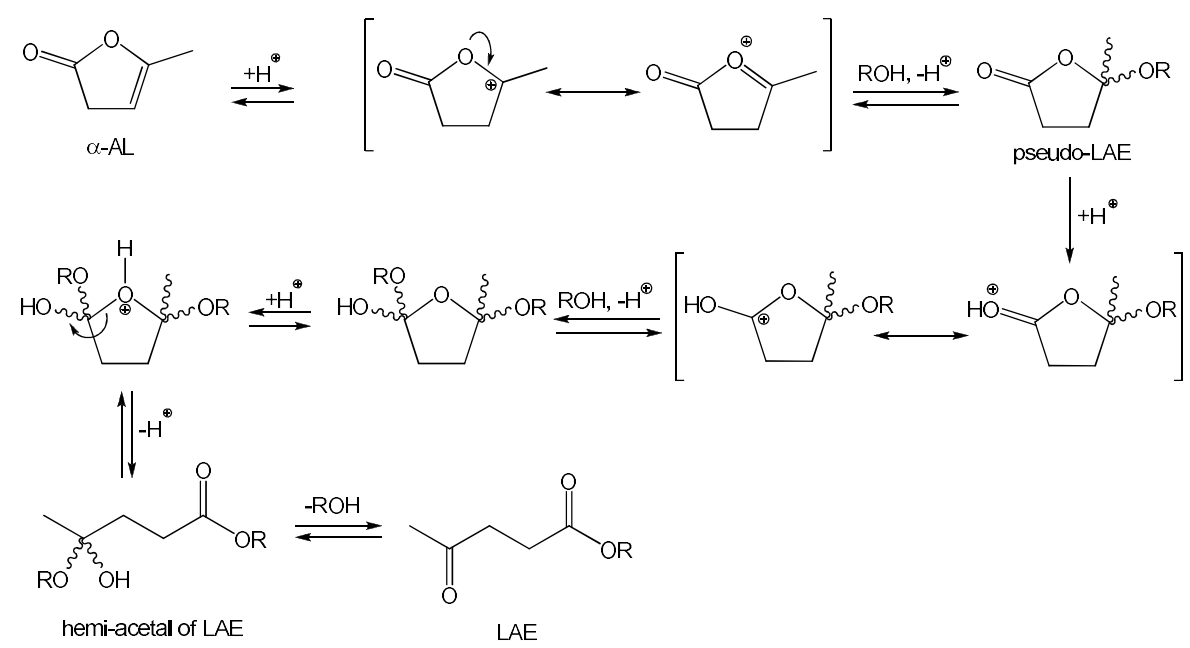

Scheme 1. The proposed mechanism for the conversion of $\alpha$-AL to LAEs. ${ }^{11}$

In this work, for the first time, the highly selective and stable catalyst for the $\alpha$-AL-to-LAEs route based on Lewis acidic triflometallate ionic liquids is presented. The catalyst was used under homogenous 
conditions as well as heterogeneous, as an active phase in the form of film supported on the solid carrier. This is the first attempt to use any form of solid-immobilised metal triflate for the synthesis of LAEs.

Recently, we have reported the first example of ionic liquids (ILs), where the traditional chlorido ligands on aluminium are replaced with trifluoromethanesulfonate (triflate, OTf) ligands. ${ }^{14}$ In analogy to chlorometallate systems, ${ }^{15,16}$ trifloaluminate ionic liquids were synthesised from [cation][OTf] and aluminium triflate. However, in contrast to chloroaluminate systems, homogenous ionic liquids were formed only for sub-stoichiometric quantities of $\mathrm{Al}(\mathrm{OTf})_{3}: \chi_{\mathrm{Al}(\mathrm{OTf}) 3}=0.15$ and 0.25 . Spectroscopic studies indicated that trifloaluminate systems contained hexacoordinate aluminium in multiply-charged, oligonuclear anionic complexes, with a variety of triflate bridging modes (Scheme 2). ${ }^{14}$ As a consequence, they are more viscous and higher melting than the chloroaluminate analogues, but have significantly improved stability against the atmospheric moisture. By Gutmann acceptor number (AN), they are medium-strength Lewis acids $(\mathrm{AN}=c a .68)$, weaker than chloroaluminate system $(\mathrm{AN}=\mathrm{ca} .96),{ }^{16}$ but still anticipated to be active acidic catalysts.

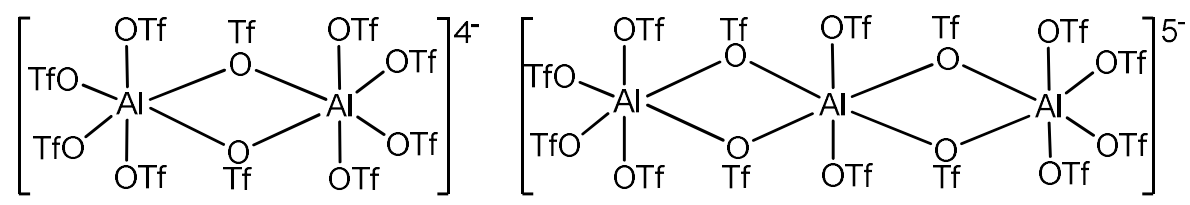

Scheme 2. Plausible anionic species present in trifloaluminate ionic liquids, close to the maximum loading of $\mathrm{Al}(\mathrm{OTf})_{3}:\left[\mathrm{Al}_{2}(\mathrm{OTf})_{10}\right]^{4-}$ and $\left[\mathrm{Al}_{3}(\mathrm{OTf})_{14}\right]^{5-} \cdot{ }^{14}$

In our previous work, trifloaluminate ionic liquids have been used as efficient acid catalysts in a solventfree, one-pot syntheses of chromane. ${ }^{14}$ It was found that immobilisation of trifloaluminate ionic liquids onto multi-wall carbon nanotubes (MWCNTs) ${ }^{17}$ to form a supported ionic liquid phase (SILP) offered numerous advantages in terms of product separation, catalyst stability, and recycling. In this work, we set to explore the application of triflate salts and triflometallate ionic liquids in the conversion of $\alpha-\mathrm{AL}$ to LAEs. 


\section{Experimental}

\section{Materials and methods}

1-Ethyl-3-methylimidazolium triflate - [C 2 mim][OTf], $\alpha$-AL, Al(III), $\mathrm{Sn}(\mathrm{II}), \mathrm{Sc}(\mathrm{III}), \mathrm{Yb}(\mathrm{III}), \mathrm{Ga}(\mathrm{III})$, La(III), Bi(III) triflates, sulphuric acid, ethanol, $n$-butanol (n-BuOH), 2-ethyl-1-hexanol and 2-methyl-1propanol were purchased from Sigma-Aldrich; MWCNTs were supplied from CheapTubes ${ }^{\mathrm{TM}}$.

${ }^{1} \mathrm{H}$ NMR spectra of LAEs were recorded using Agilent 400-MR, at the following operating frequencies: ${ }^{1} \mathrm{H} 399.89 \mathrm{MHz},{ }^{13} \mathrm{C} 150.90 \mathrm{MHz}$. NMR spectra of ionic liquids were recorded using Bruker AVANCE 400, at the following operating frequencies: ${ }^{1} \mathrm{H} 399.78 \mathrm{MHz},{ }^{13} \mathrm{C} 100.53 \mathrm{MHz}$. Chemical shifts are reported as parts per million in reference to tetramethylsilane (TMS).

Gas chromotography (GC) analyses were performed using a SHIMADZU GC-2010 Plus equipped with a Zebron ZB-5MSi column $(30 \mathrm{~m} \times 0.32 \mathrm{~mm} \times 0.25 \mu \mathrm{m}$ film). GC-MS (gas chromatography-mass spectrometry) analyses were performed using an Agilent gas chromatograph 7890C (HP-5 MS capillary column, $30 \mathrm{~m} \times 0.25 \mathrm{~mm} \times 0.25 \mu \mathrm{m}$ ), conjugated with an Agilent mass spectrometer $5975 \mathrm{C}$ with EI ionization $(70 \mathrm{eV})$. The products were identified using the NIST/EPA/NIH Mass Spectral Library.

Nitrogen adsorption/desorption isotherms for the carbon nanomaterials were obtained using a Micrometrics ASAP $2420 \mathrm{M}$ instrument at $-196^{\circ} \mathrm{C}$ to calculate their specific surface areas ( $\mathrm{S}$ BET) and pore volumes. The size of the pores was obtained using the Barrett-Joyner-Halenda (BJH) method with the Kruk-Jaroniec-Sayari correction. Prior to the experiments, the samples were out-gassed at $200{ }^{\circ} \mathrm{C}$ and $1.33 \cdot 10^{-3} \mathrm{~Pa}$ for $5 \mathrm{~h}$.

Thermogravimetric analyses (TGA) were carried out using a Mettler-Toledo STAR851 thermobalance. Samples of approximately 5-10 mg were heated in $70 \mu \mathrm{L} \mathrm{Al}_{2} \mathrm{O}_{3}$ crucibles from 25 to $800{ }^{\circ} \mathrm{C}$ at $20^{\circ} \mathrm{C} \cdot \mathrm{min}^{-}$ 1, under nitrogen flow of $100 \mathrm{~mL} \cdot \mathrm{min}^{-1}$. Thermogravimetric (TG) and thermogravimetric derivative (DTG) curves were recorded (SI, Figs. S1-S5).

Method for the calculation of turnover number (TON) and turnover frequency (TOF): 
TON $=$ yield of product [\%]*amount of moles of $\alpha-\mathrm{AL}[\mathrm{mol}] /$ amount of moles of the catalyst [mol] $\mathrm{TOF}=\mathrm{TON} /$ reaction time $[\mathrm{min}]$

\section{Synthetic procedures}

Triflometallate ionic liquids were prepared at $1 \mathrm{~g}$ scale in a glove box, by weighing the appropriate masses of $\left[\mathrm{C}_{2} \mathrm{mim}\right][\mathrm{OTf}]$ and $\mathrm{Al}(\mathrm{OTf})_{3}\left(\right.$ molar ratios $\chi_{\mathrm{Al}(\mathrm{OTf}) 3}=0.15$ or 0.25$)$ into a vial and stirring the reaction mixtures at $85^{\circ} \mathrm{C}$ until homogenous. The ionic liquids were further used without purification.

$\left[\mathrm{C}_{2} \mathrm{mim}\right][\mathrm{OTf}]-\mathrm{Al}(\mathrm{OTf})_{3}, \chi_{\mathrm{Al}(\mathrm{OTf}) 3}=0.15:{ }^{1} \mathrm{H} \mathrm{NMR}(\mathrm{DMSO}, 400 \mathrm{MHz}, 360 \mathrm{~K}): \delta 0.83(\mathrm{~m}, 3 \mathrm{H}), 3.26(\mathrm{~s}$, 3H), 3.58 (m, 2H), $6.81(\mathrm{~s}, 1 \mathrm{H}), 6.87(\mathrm{~s}, 1 \mathrm{H}), 8.05(\mathrm{~s}, 1 \mathrm{H}) .{ }^{13} \mathrm{C}$ NMR (DMSO, $\left.400 \mathrm{MHz}, 360 \mathrm{~K}\right): \delta$ 13.49, $34.94,44.15,119.51\left(\mathrm{q},{ }^{1} \mathrm{~J}_{\mathrm{CF}}=318 \mathrm{~Hz}\right), 121.30,122.97,135.54$.

$\left[\mathrm{C}_{2} \mathrm{mim}\right][\mathrm{OTf}]-\mathrm{Al}(\mathrm{OTf})_{3}, \chi_{\mathrm{Al}(\mathrm{OTf}) 3}=0.25:{ }^{1} \mathrm{H} \mathrm{NMR}(\mathrm{DMSO}, 400 \mathrm{MHz}, 360 \mathrm{~K}): \delta 0.83(\mathrm{~m}, 3 \mathrm{H}) ; 3.26(\mathrm{~s}$, 3H), $3.58(\mathrm{~m}, 2 \mathrm{H}), 6.81(\mathrm{~s}, 1 \mathrm{H}), 6.87(\mathrm{~s}, 1 \mathrm{H}), 8.05(\mathrm{~s}, 1 \mathrm{H}) .{ }^{13} \mathrm{C}$ NMR (DMSO, $\left.400 \mathrm{MHz}, 360 \mathrm{~K}\right): \delta 13.49$, $34.94,44.15,119.51\left(\mathrm{q},{ }^{1} \mathrm{~J}_{\mathrm{CF}}=318 \mathrm{~Hz}\right), 121.30,122.97,135.54$.

MWCNT-[C ${ }_{2}$ mim] $[\text { OTf]-Al(OTf) })_{3}, \chi_{\text {Al(OTf)3 }}=0.25$ was prepared by placing the ionic liquid, $\left[\mathrm{C}_{2} \mathrm{mim}\right]\left[\mathrm{Al}(\mathrm{OTf})_{6}\right] \chi_{\mathrm{Al}(\mathrm{OTf}) 3}=0.25(0.200 \mathrm{~g})$, MWCNTs $(0.400 \mathrm{~g})$ and $n$-hexane $(10 \mathrm{~mL})$ in a $25 \mathrm{~mL}$ round-bottomed flask, which was then sealed with a septum. The content was combined using an ultrasonic bath $\left(20^{\circ} \mathrm{C}, 2 \mathrm{~h}\right)$. Afterwards, the mixture was filtered through a Büchner funnel, the catalyst was washed with $15 \mathrm{~mL} n$-hexane, and the solvent was removed at $50{ }^{\circ} \mathrm{C}$ under vacuum (Schlenk line) for $2 \mathrm{~h}$. The ionic liquid loading (as determined by TGA) was $13.8 \mathrm{wt} \%$.

$\boldsymbol{n}$-Butyl levulinate was synthesised by the addition of the catalyst: $\mathrm{Al}(\mathrm{OTf})_{3}(0.010 \mathrm{~g}, 0.025 \mathrm{mmol}, 0.1$ $\operatorname{mol} \%$ per $\alpha-\mathrm{AL})$ or trifloaluminate ionic liquids $\left[\mathrm{C}_{2} \mathrm{mim}\right][\mathrm{OTf}]-\mathrm{Al}(\mathrm{OTf})_{3}, \chi_{\mathrm{Al}(\mathrm{OTf}) 3}=0.25(0.006 \mathrm{~g}, 0.02$ $\operatorname{mol} \%$ per $\alpha-\mathrm{AL})$ or MWCNT-[C 2 mim][OTf]-Al(OTf) $3, \chi_{\mathrm{Al}(\mathrm{OTf}) 3}=0.25(0.036 \mathrm{~g}, 0.013 \mathrm{~mol} \%$ of IL per $\alpha$-AL) to a solution of $n$-butanol $(1.853 \mathrm{~g}, 25 \mathrm{mmol})$ and $\alpha$-AL $(2.455 \mathrm{~g}, 25 \mathrm{mmol})$, stirred vigorously at $60{ }^{\circ} \mathrm{C}$. Reaction progress was monitored by GC. After completion, $n$-hexane $(3 \mathrm{~mL})$ was added to the post-reaction mixture, resulting in precipitation of $\mathrm{Al}(\mathrm{OTf})_{3}$ or phase-separation of the ionic liquid. In 
case of MWCNT-[ $\left.\mathrm{C}_{2} \mathrm{mim}\right][\mathrm{OTf}]-\mathrm{Al}(\mathrm{OTf})_{3}, \chi_{\mathrm{Al}(\mathrm{OTf}) 3}=0.25$, the catalyst was separated by filtration and washed with $n$-hexane. The organic phase was washed with water, dried over the anhydrous $\mathrm{MgSO}_{4}$, and after evaporation of solvent using rotary evaporator $\left(60^{\circ} \mathrm{C}, 150 \mathrm{mbar}\right) n$-butyl levulinate was obtained in $99 \%$ yield.

n-Butyl levulinate: $\left({ }^{1} \mathrm{H}-\mathrm{NMR}, 400 \mathrm{MHz}, \mathrm{CDCl}_{3}\right.$, TMS): $\delta 0.89$ (t, J=7.4 Hz, 3H), 1.40-1.28 (m, 2H), $1.63-1.50(\mathrm{~m}, 2 \mathrm{H}), 2.16(\mathrm{~s}, 3 \mathrm{H}), 2.54(\mathrm{t}, \mathrm{J}=6.5 \mathrm{~Hz}, 2 \mathrm{H}), 2.71(\mathrm{t}, \mathrm{J}=6.6 \mathrm{~Hz}, 2 \mathrm{H}), 4.04(\mathrm{t}, \mathrm{J}=6.7 \mathrm{~Hz}, 2 \mathrm{H})$. 13C NMR (150 MHz, $\left.\mathrm{CDCl}_{3}\right): \delta 13.63,19.04,27.96,29.81,30.57,37.92,64.49,172.76,206.61$; GCMS: (EI) m/z (\%) $172\left(3, \mathrm{M}^{+}\right), 157$ (8), 143 (3), 130 (6), 117 (15), 99 (90), 81 (5), 74 (28), 71 (12), 57 (18), $43(100)$.

Alkyl levulinates were synthesised by the addition of the catalyst: trifloaluminate ionic liquid $\left[\mathrm{C}_{2} \mathrm{mim}\right][\mathrm{OTf}]-\mathrm{Al}(\mathrm{OTf})_{3}, \chi_{\mathrm{Al}(\mathrm{OTf}) 3}=0.25(0.006 \mathrm{~g} ; 0.02 \mathrm{~mol} \% \%$ per $\alpha-\mathrm{AL})$ to solution of alcohol $(1.150 \mathrm{~g}$ of ethanol, $1.503 \mathrm{~g}$ of 2-methyl-1-propanol or $3.256 \mathrm{~g}$ of 2-ethyl-1-hexanol; $25 \mathrm{mmol})$ and $\alpha$-AL (2.455 g, $25 \mathrm{mmol}$ ), stirred vigorously at $60{ }^{\circ} \mathrm{C}$. Reaction progress was monitored by GC. After completion, $n$ hexane $(3 \mathrm{~mL})$ was added to the post-reaction mixture, resulting in phase-separation of the ionic liquid. After separation of the catalyst, the organic phase was washed with water, dried and after the evaporation of solvent, alkyl levulinates were isolated in $99 \%$ yields.

Ethyl levulinate: ( ${ }^{1} \mathrm{H}-\mathrm{NMR}, 400 \mathrm{MHz}, \mathrm{CDCl}_{3}$, TMS): $\delta 1.26(\mathrm{t}, \mathrm{J}=7.1 \mathrm{~Hz}, 3 \mathrm{H}), 2.20(\mathrm{~s}, 3 \mathrm{H}), 2.57$ (t, $\mathrm{J}=6.6 \mathrm{~Hz}, 2 \mathrm{H}), 2.75(\mathrm{t}, \mathrm{J}=6.6 \mathrm{~Hz}, 2 \mathrm{H}), 4.13(\mathrm{t}, \mathrm{J}=7.1 \mathrm{~Hz}, 2 \mathrm{H}) .{ }^{13} \mathrm{C} \mathrm{NMR}\left(150 \mathrm{MHz}, \mathrm{CDCl}_{3}\right): \delta 14.27$, 28.13, 29.99, 38.07, 60.74, 172.86, 206.83; GC-MS: (EI) m/z (\%) 144 (15, M+*), 129 (30), 115 (8), 99 (67), $71(25), 55$ (27), 43 (100).

2-methyl-1-propyl levulinate: ( $\left.{ }^{1} \mathrm{H}-\mathrm{NMR}, 400 \mathrm{MHz}, \mathrm{CDCl}_{3}, \mathrm{TMS}\right): \delta 0.93$ (d, J=6.7 Hz, 6H), $1.97-1.87$ (m, 1H), $2.20(\mathrm{~s}, 3 \mathrm{H}), 2.59(\mathrm{t}, \mathrm{J}=6.6 \mathrm{~Hz}, 2 \mathrm{H}), 2.76(\mathrm{t}, \mathrm{J}=6.6 \mathrm{~Hz}, 2 \mathrm{H}), 3.86(\mathrm{~d}, \mathrm{~J}=6.7 \mathrm{~Hz}, 2 \mathrm{H}) .{ }^{13} \mathrm{C} \mathrm{NMR}$ $\left(150 \mathrm{MHz}, \mathrm{CDCl}_{3}\right): \delta 19.17,27.81,28.10,29.99,38.10,70.89,172.91,206.80 ;$ GC-MS: (EI) m/z (\%) 172 $\left(3, \mathrm{M}^{+\cdot}\right), 157$ (7), $130(5), 117(20), 99$ (100), 81 (6), 71 (23), 57 (27), 43 (80). 
2-ethyl-1-hexyl levulinate: ( $\left.{ }^{1} \mathrm{H}-\mathrm{NMR}, 400 \mathrm{MHz}, \mathrm{CDCl}_{3}, \mathrm{TMS}\right): \delta 0.93-0.85(\mathrm{~m}, 6 \mathrm{H}), 1.32-1.24(\mathrm{~m}$, $6 \mathrm{H}), 1.41-1.32(\mathrm{~m}, 2 \mathrm{H}), 1.63-1.51(\mathrm{~m}, 1 \mathrm{H}), 2.19(\mathrm{~s}, 3 \mathrm{H}), 2.58(\mathrm{t}, \mathrm{J}=6.6 \mathrm{~Hz}, 2 \mathrm{H}), 2.75(\mathrm{t}, \mathrm{J}=6.6 \mathrm{~Hz}, 2 \mathrm{H})$, $4.04-3.94(\mathrm{~m}, 2 \mathrm{H}) .{ }^{13} \mathrm{C} \mathrm{NMR}\left(150 \mathrm{MHz}, \mathrm{CDCl}_{3}\right): \delta 10.95,14.02,22.95,23.73,28.01,28.89,29.85$, 30.36, 37.98, 38.70, 67.10, 172.89, 206.62; GC-MS: (EI) m/z (\%) 185 (4, M+*), 171 (5), 155 (4), 142 (4), 127 (5), 112 (24), 99 (100), 83 (10), 71 (24), 57 (23), 43 (61).

Studies of the catalyst stability via a semi-continuous substrate addition: The reaction was carried out at $60{ }^{\circ} \mathrm{C}$ (molar ratio $\alpha-\mathrm{Al}: n-\mathrm{BuOH} 1: 1,5 \mathrm{mmol} ; 0.1 \mathrm{~mol} . \%$ of $\left[\mathrm{C}_{2} \operatorname{mim}\right][\mathrm{OTf}]-\mathrm{Al}(\mathrm{OTf}) 3, \chi_{\mathrm{Al}(\mathrm{OTf}) 3}=$ 0.25). The next portions of reagents ( $5 \mathrm{mmol}$ of $\alpha$-AL and $5 \mathrm{mmol}$ of $n$ - $\mathrm{BuOH}$ ) were added after 20,40 , $60,90,130$. The reaction progress was monitored by GC. The last sample was analysed after and 175 $\min$ of the reaction.

Recycling of MWCNT-[C $\left.\mathrm{C}_{2} \mathrm{mim}\right][\mathrm{OTf}]-\mathrm{Al}(\mathrm{OTf})_{3}, \chi_{\mathrm{Al}(\mathrm{OTf}) 3}=\mathbf{0 . 2 5}$ was tested in reactions carried out as described above, but scaled up by a factor of five. After completion of the reaction, $n$-hexane was added $(10 \mathrm{~mL})$ and MWCNT-[C $\left.\mathrm{C}_{2} \mathrm{mim}\right][\mathrm{OTf}]-\mathrm{Al}(\mathrm{OTf})_{3}, \chi_{\mathrm{Al}(\mathrm{OTf}) 3}=0.25$ was separated by filtration $(0.180 \mathrm{~g})$ and washed with $n$-hexane. The catalyst was dried at $60{ }^{\circ} \mathrm{C}$ under vacuum (Schlenk line) for $1 \mathrm{~h}$ and used for the next cycle.

\section{Results and Discussion}

\section{Synthesis of a model $n$-butyl levulinate catalysed by metal triflates}

In a preliminary screening, a range of metal triflates: $\mathrm{Sn}(\mathrm{OTf})_{2}, \mathrm{Bi}(\mathrm{OTf})_{3}, \mathrm{Ga}(\mathrm{OTf})_{3}, \mathrm{Yb}(\mathrm{OTf})_{3}$, $\mathrm{Sc}(\mathrm{OTf})_{3}, \mathrm{La}(\mathrm{OTf})_{3}$ and $\mathrm{Al}(\mathrm{OTf})_{3}$, were tested as catalysts in a model reaction of $\alpha$-AL with $n$-butanol (Scheme 3), which was selected as a representative of medium-alkyl chain length alcohol.

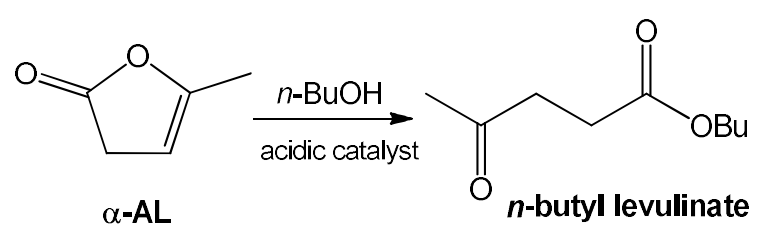

Scheme 3. Conversion of $\alpha$-AL to $n$-butyl levulinate 
Equimolar quantities of $\alpha$-AL and $n$-butanol were reacted at $60^{\circ} \mathrm{C}$ under solventless conditions, in the presence of $0.02-1.00 \mathrm{~mol} \%$ metal triflates. In all cases, metal triflates were suspended (only partly dissolved) in the reaction mixture, which is common for these salts, generally characterised by poor solubility of these salts in organic solvents. The influence of the catalyst on conversion and selectivity is shown in Table 1.

Table 1. The influence of the metal triflate catalyst type and loading on the reaction of $\alpha$-AL with $n$ butanol to form $n$-butyl levulinate, compared to $\mathrm{H}_{2} \mathrm{SO}_{4}$ catalyst as the benchmark

\begin{tabular}{|c|c|c|c|c|c|}
\hline Catalyst & Catalyst, mol\% & Conversion, $\%$ & Selectivity, \% & TON & TOF, $\min ^{-1}$ \\
\hline $\mathrm{Sn}(\mathrm{OTf})_{2}$ & 1 & 94 & 95 & $8.9 * 10^{3}$ & $1.5 * 10^{2}$ \\
\hline $\mathrm{Bi}(\mathrm{OTf})_{3}$ & 1 & 100 & 87 & $8.7 * 10^{3}$ & $1.5 * 10^{2}$ \\
\hline $\mathrm{La}(\mathrm{OTf})_{3}$ & 1 & 94 & 79 & $7.4 * 10^{3}$ & $1.2 * 10^{2}$ \\
\hline $\mathrm{Yb}(\mathrm{OTf})_{3}$ & 1 & 100 & 83 & $8.3 * 10^{3}$ & $1.4 * 10^{2}$ \\
\hline $\mathrm{Ga}(\mathrm{OTf})_{3}$ & 1 & 99 & 92 & $9.1 * 10^{3}$ & $1.5^{*} 10^{2}$ \\
\hline $\mathrm{Ga}(\mathrm{OTf})_{3}$ & 0.1 & 78 & 88 & $6.9 * 10^{4}$ & $1.1 * 10^{3}$ \\
\hline $\operatorname{Sc}(\mathrm{OTf})_{3}$ & 1 & 100 & 88 & $8.8 * 10^{3}$ & $1.5^{*} 10^{2}$ \\
\hline $\mathrm{Sc}(\mathrm{OTf})_{3}$ & 0.1 & 92 & 85 & $7.8 * 10^{4}$ & $1.3 * 10^{3}$ \\
\hline $\mathrm{Al}(\mathrm{OTf})_{3}$ & 1 & 97 & 96 & $9.3 * 10^{3}$ & $1.6 * 10^{2}$ \\
\hline $\mathrm{Al}(\mathrm{OTf})_{3}$ & 0.1 & 81 & 83 & $6.7 * 10^{4}$ & $1.1 * 10^{3}$ \\
\hline $\mathrm{Al}(\mathrm{OTf})_{3}$ & 0.02 & 52 & 77 & $2.0 * 10^{5}$ & $3.3 * 10^{3}$ \\
\hline $\mathrm{H}_{2} \mathrm{SO}_{4} *$ & 0.1 & 100 & 93 & $9.3 * 10^{4}$ & $1.6 * 10^{3}$ \\
\hline
\end{tabular}

Reaction conditions: molar ratio $n$-BuOH: $\alpha$-AL $1: 1 ; 60^{\circ} \mathrm{C}$; reaction time $60 \mathrm{~min}$, all experiments were performed in triplicate and the results for each of the three measurements differed by less than $1 \%$; conversion and selectivity were determined by GC.

In general, high conversions of $\alpha$-AL were achieved, reaching $94-100 \%$ in the presence of $1 \mathrm{~mol} \%$ of $\mathrm{Sn}(\mathrm{OTf})_{2}, \mathrm{Bi}(\mathrm{OTf})_{3}, \mathrm{La}(\mathrm{OTf})_{3}, \mathrm{Yb}(\mathrm{OTf})_{3}$ or $\mathrm{Ga}(\mathrm{OTf})_{3}$; however, selectivities to $n$-butyl levulinate were oscillating at $79-95 \%$. The most active was $\mathrm{Sc}(\mathrm{OTf})_{3}$, reaching high conversion even at lower loading $(0.1$ 
mol.\%), but the selectivity was rather poor (85\%). It was $\mathrm{Al}(\mathrm{OTf})_{3}$ that gave the highest selectivity (96\%), combined with high conversion, as well as best TON $\left(9.3^{*} 10^{3}\right)$ and TOF $\left(1.6^{*} 10^{2}, \mathrm{~min}^{-1}\right)$ at $1 \mathrm{~mol} \%$ loading (97\%); marginally worse was the result of $\mathrm{Sn}(\mathrm{OTf})_{2}$, with conversion at $94 \%$ and selectivity at $95 \%$ at 1 mol\% loading.

No triflate salts were better than the benchmark $\mathrm{H}_{2} \mathrm{SO}_{4}$ catalyst, which gave $100 \%$ conversion and $93 \%$ selectivity at $0.1 \%$ loading; however, this catalyst caused the dark brown colour of the reaction mixture and the recycle of this catalyst is rather no possible. At the same time, metal triflates also have shortcomings. Firstly, their partial solubility in the reaction mixture precluded easy recovery of the catalyst via filtration. Secondly, most metal triflates are very expensive, with the prices of $\operatorname{Sn}(\mathrm{OTf})_{2}$, $\mathrm{Sc}(\mathrm{OTf})_{3}$ and $\mathrm{Yb}(\mathrm{OTf})_{3}$ falling between 30 and 70 Euro per $1 \mathrm{~g}$ (Sigma-Aldrich). The least expensive are $\mathrm{Ga}(\mathrm{OTf})_{3}(17$ Euro per $1 \mathrm{~g})$ and $\mathrm{Al}(\mathrm{OTf})_{3}(6$ Euro per $1 \mathrm{~g})$.

Considering superior performance combined with the lowest price, $\mathrm{Al}(\mathrm{OTf})_{3}$ was selected to be tested as a neat triflometallate ionic liquid and as a supported ionic liquid phase, in the hope to develop an inexpensive and highly selective catalyst, with enhanced recycling compared to $\mathrm{Al}(\mathrm{OTf})_{3}$.

\section{Synthesis of alkyl levulinates catalysed by trifloaluminate ionic liquids}

Aluminium triflate was reacted with $\left[\mathrm{C}_{2} \mathrm{mim}\right][\mathrm{OTf}]$, at $1: 3$ molar ratio $\left(\chi_{\mathrm{Al}(\mathrm{OTf}) 3}=0.25\right)$, which gives the highest attainable loading of aluminium in the homogenous liquid $\left(\left[\mathrm{C}_{2} \mathrm{mim}\right][\mathrm{OTf}]-\mathrm{Al}(\mathrm{OTf})_{3}, \chi_{\mathrm{Al}(\mathrm{OTf}) 3}\right.$ $=0.25)$. For comparison, a system with lower aluminium loading, $\left[\mathrm{C}_{2} \mathrm{mim}\right][\mathrm{OTf}]-\mathrm{Al}(\mathrm{OTf})_{3}, \chi_{\mathrm{Al}(\mathrm{OTf}) 3}=$ 0.15 was also synthesised. The influence of the key reaction parameters: temperature, catalyst loading and reaction time on the conversion of $\alpha$-AL and selectivity to LAE were determined (Table 2). In all cases, the ionic liquid catalyst was fully dissolved in the reaction mixture, enabling truly homogenous conditions. 
Table 2. The influence of the catalyst loading and reaction conditions on the reaction of $\alpha-\mathrm{AL}$ with $n$-butanol to form $n$-butyl levulinate, with the $\left[\mathrm{C}_{2} \mathrm{mim}\right][\mathrm{OTf}]-\mathrm{Al}(\mathrm{OTf})_{3}, \chi_{\mathrm{Al}(\mathrm{OTf}) 3}=0.25$ ionic liquid used as a catalyst.

\begin{tabular}{lllcccc}
\hline $\begin{array}{l}\text { Catalyst, } \\
\text { mol } \%\end{array}$ & Temp, ${ }^{\circ} \mathrm{C}$ & Time, min & Conversion, $\%$ & Selectivity, $\%$ & TON & TOF, min $^{-1}$ \\
\hline 2 & 20 & 180 & 100 & $>99$ & $5.0^{*} 10^{3}$ & 28 \\
1 & 20 & 180 & 82 & 94 & $7.7^{*} 10^{3}$ & 43 \\
1 & 20 & 240 & 96 & 97 & $9.3^{*} 10^{3}$ & 39 \\
1 & 20 & 300 & 100 & $>99$ & $1.0^{*} 10^{4}$ & 33 \\
1 & 40 & 180 & 98 & $>99$ & $9.8^{*} 10^{3}$ & 54 \\
1 & 60 & 5 & 100 & $>99$ & $1.0^{*} 10^{4}$ & $5.0^{*} 10^{3}$ \\
0.1 & 60 & 20 & 100 & $>99$ & $1.0^{*} 10^{5}$ & $5.0^{*} 10^{3}$ \\
0.02 & 60 & 60 & 100 & $>99$ & $5.0^{*} 10^{5}$ & $8.3^{*} 10^{3}$ \\
$0.02^{a}$ & 60 & 240 & 100 & $>99$ & $5.0^{*} 10^{5}$ & $2.1^{*} 10^{3}$ \\
0.004 & 60 & 180 & 100 & $>99$ & $2.5^{*} 10^{6}$ & $1.4^{*} 10^{4}$ \\
0.002 & 60 & 600 & 100 & $>99$ & $5.0^{*} 10^{6}$ & $8.3^{*} 10^{3}$
\end{tabular}

Reaction conditions: molar ratio $n$-BuOH: $\alpha-\mathrm{AL} 1: 1 ;\left[\mathrm{C}_{2} \operatorname{mim}\right][\mathrm{OTf}]-\mathrm{Al}(\mathrm{OTf})_{3}, \chi_{\mathrm{Al}(\mathrm{OTf}) 3}=0.25$; all experiments were performed in triplicate and the results for each of the three measurements differed by less than $1 \%$; conversion and selectivity were determined using GC.

${ }^{a}\left[\mathrm{C}_{2} \operatorname{mim}\right][\mathrm{OTf}]-\mathrm{Al}(\mathrm{OTf})_{3}, \chi_{\mathrm{Al}(\mathrm{OTf}) 3}=0.15$

The reaction carried out at ambient temperature $\left(20{ }^{\circ} \mathrm{C}\right)$ with $2 \mathrm{~mol} \%$ of $\left[\mathrm{C}_{2}\right.$ mim $][\mathrm{OTf}]-\mathrm{Al}(\mathrm{OTf})_{3}$, $\chi_{\mathrm{Al}(\mathrm{OTf}) 3}=0.25$ resulted in the full conversion of $\alpha-\mathrm{AL}$ and high selectivity toward the appropriate LAE (>99\%) after $180 \mathrm{~min}$. Lowering the catalyst loading to $1 \%$ gave full conversion and $>99 \%$ selectivity within 300 min. Maintaining the $1 \%$ catalyst loading, full conversions and $>99 \%$ selectivity were reached after $180 \mathrm{~min}$ at $40{ }^{\circ} \mathrm{C}$, and after just $5 \mathrm{~min}$ at $60^{\circ} \mathrm{C}$ - which was a dramatic improvement over the performance of neat $\mathrm{Al}(\mathrm{OTf})_{3}$, which under the same conditions gave $97 \%$ conversion after $60 \mathrm{~min}$, and 
with inferior selectivity of $96 \%$ (Table 1). At lower loadings of the $\left[\mathrm{C}_{2} \mathrm{mim}\right][\mathrm{OTf}]-\mathrm{Al}(\mathrm{OTf})_{3}, \chi_{\mathrm{Al}(\mathrm{OTf}) 3}=$ 0.25 catalyst, reaction times required to reach full conversion were understandably longer, reaching $10 \mathrm{~h}$ for $0.002 \mathrm{~mol} \%$ (Table 2). Similarly, activity dropped for the ionic liquid with lower $\mathrm{Al}(\mathrm{OTf})_{3}$ content, $\left[\mathrm{C}_{2} \mathrm{mim}\right][\mathrm{OTf}]-\mathrm{Al}(\mathrm{OTf})_{3}, \chi_{\mathrm{Al}(\mathrm{OTf}) 3}=0.15$. TON values for low catalyst loadings were very high $\left(2.5^{*} 10^{6}\right.$ for $0.004 \mathrm{~mol} \%, 5.0^{*} 10^{6}$ for $\left.0.002 \mathrm{~mol} \%\right)$, with best TOF reached for the $0.004 \mathrm{~mol} \%$ loading $\left(1.4 * 10^{4}\right.$ $\left.\min ^{-1}\right)$.

Robustness of the trifloaluminate ionic liquid catalyst was tested in the reaction of $\alpha$-AL with three other alcohols (Table 3$)$, under moderate conditions $\left(0.1 \mathrm{~mol} \%\right.$ of $\left[\mathrm{C}_{2} \mathrm{mim}\right][\mathrm{OTf}]-\mathrm{Al}(\mathrm{OTf})_{3}, \chi_{\mathrm{Al}(\mathrm{OTf}) 3}=$ $\left.0.25 ; 60^{\circ} \mathrm{C}\right)$. In all cases, extremely high selectivities ( $\left.>99 \%\right)$ and full conversions were achieved between 15 and $45 \mathrm{~min}$. The progress of the reactions was controlled by GC and the optimum reactions times were determined after reaching full conversion of $\alpha$-AL. This compares very favourably with the literature, where the reaction of $\alpha-\mathrm{AL}$ and ethanol at $75{ }^{\circ} \mathrm{C}$ in the presence of Amberlyst 36 gave ethyl levulinate at $91 \%$ selectivity, with nearly-full conversion achieved after $180 \mathrm{~min}$, whereas the reaction of $\alpha-\mathrm{AL}$ and octanol gave $n$-octyl levulinate at 94\% selectivity, with full conversion of $\alpha$-AL reached after 300 min. ${ }^{11}$

Table 3. The influence of the alcohol on the conversion of $\alpha-A L$ to LAEs, with the $\left[\mathrm{C}_{2} \mathrm{mim}\right][\mathrm{OTf}]-$ $\mathrm{Al}(\mathrm{OTf})_{3}, \chi_{\mathrm{Al}(\mathrm{OTf}) 3}=0.25$ ionic liquid used as a catalyst.

\begin{tabular}{llllll}
\hline Alcohol & Time, min & Conversion, $\%$ & Selectivity, $\%$ & TON & TOF, min $^{-1}$ \\
\hline ethanol & 15 & 100 & $>99$ & $1.0^{*} 10^{5}$ & $6.7 * 10^{3}$ \\
2-methyl-1-propanol & 20 & 100 & $>99$ & $1.0^{*} 10^{5}$ & $5.0^{*} 10^{3}$ \\
2-ethyl-1-hexanol & 45 & 100 & $>99$ & $1.0^{*} 10^{5}$ & $2.2 * 10^{3}$ \\
\hline
\end{tabular}

Reaction conditions: molar ratio alcohol: $\alpha-\mathrm{AL} 1: 1 ; 60{ }^{\circ} \mathrm{C} ; 0.1 \mathrm{~mol} \%$ of $\left[\mathrm{C}_{2} \mathrm{mim}\right][\mathrm{OTf}]-\mathrm{Al}(\mathrm{OTf})_{3}, \chi_{\mathrm{Al}(\mathrm{OTf}) 3}$ $=0.25$; all experiments were performed in triplicate and the results for each of the three measurements differed by less than $1 \%$; conversion and selectivity were determined using GC. 
Catalyst recovery could be achieved in a simple one-step process: after the reaction was completed, $n$ butyl levulinate was isolated via extraction with $n$-hexane. Upon the addition of $n$-hexane, ionic liquid phase-separated as the bottom phase from the reaction mixture, and was easily isolated by decantation of the organic phase. However, when using low catalyst loadings at a small scale $(0.002 \mathrm{~mol} \%$, which translates to $0.0006 \mathrm{~g}$ of the catalyst per $2.5 \mathrm{~g}$ of $\alpha-\mathrm{AL})$, it was more practical to extract the ionic liquid with water from the post-reaction mixtures.

In all cases, after $n$-hexane was evaporated from the organic phase, $n$-butyl levulinate was obtained with high purity (>99\%) and high isolated yield (99\%). The structure and purity were confirmed using ${ }^{1} \mathrm{H},{ }^{13} \mathrm{C}$ NMR spectroscopy and GC-MS.

Taking into consideration technical difficulties in the recovery of catalyst at a low loading without a significant reaction scale up, a semi-continuous addition of the substrate was used to demonstrate reusability of the catalytic system. The reaction was carried out at $60^{\circ} \mathrm{C}$ (molar ratio $\alpha$-Al: $n$ - $\mathrm{BuOH} 1: 1$, $5 \mathrm{mmol} ; 0.1 \mathrm{~mol} . \%$ of $\left.\left[\mathrm{C}_{2} \mathrm{mim}\right][\mathrm{OTf}]-\mathrm{Al}(\mathrm{OTf})_{3}, \chi_{\mathrm{Al}(\mathrm{OTf}) 3}=0.25\right)$. The next portions of reagents $(5 \mathrm{mmol}$ of $\alpha$-AL and $5 \mathrm{mmol}$ of $n-\mathrm{BuOH}$ ) were added after 20, 40, 60, 90 and $130 \mathrm{~min}$. The reaction progress was monitored by GC. The last sample was analysed after 175 min of the reaction.

The reaction started with $5 \mathrm{mmol}$ of each reagent, and the catalyst has been demonstrated to remain active for six consecutive runs (Figure 1). With every addition, the catalyst concentration was decreased, which is the probable cause of lower yields achieved in the last three runs even if the longer reaction times were applied. The reaction times necessary to achieved the yields presented in Figure 1 (to convert the another portions of reactants) were 20 minutes for the first 3 portions, and 30, 40 and 45 min for the following ones. After the $3^{\text {rd }}$ addition of reactants the conversion (100\%) and selectivity ( $\left.>99 \%\right)$ were still high. Follow-up the addition of next portions the conversion was degreased (up to $88 \%$ after $6^{\text {th }}$ portion) and selectivity dropped down to $92 \%$. 


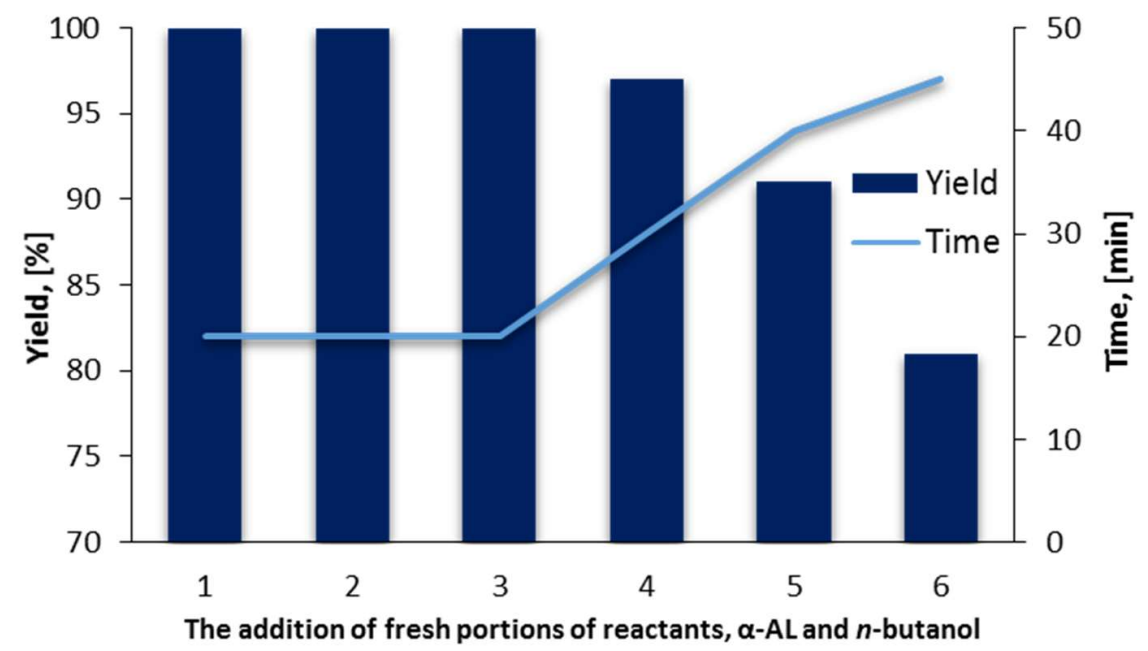

Figure 1. Activity of the catalytic system $\left[\mathrm{C}_{2} \mathrm{mim}\right][\mathrm{OTf}]-\mathrm{Al}(\mathrm{OTf})_{3}, \chi_{\mathrm{Al}(\mathrm{OTf}) 3}=0.25$ in semi-continuous addition of the substrates ( $\alpha-\mathrm{AL}$ and $n-\mathrm{BuOH})$; time necessary to reach adequate yield after addition of the next portions of reactants. All experiments were performed in triplicate, with results differing by less than $1 \%$; yield was determined using GC.

Experiments reported above clearly demonstrated that the trifloaluminate ionic liquid tested here is a promising catalyst for the synthesis of LAEs from $\alpha$-AL, offering high catalytic activity, excellent selectivity and the potential for efficient recycle - superior to the literature data. However, recovery and recycle of the small amount of the catalyst was found problematic, and upon scale-up large quantities of $n$-hexane would be required. In the effort to limit the use of auxiliary organic solvents, it was decided to deposit the ionic liquid on a solid support, and use it as a SILP (supported ionic liquid phase) catalyst, where the reaction occurs in a thin film of ionic liquid performing under homogenous conditions. ${ }^{27,28}$

\section{Synthesis of $n$-butyl levulinate catalysed by trifloaluminate ionic liquids immobilised on carbon nanotubes}

Carbon nanotubes (CNTs) offer numerous advantages as a catalyst support, which includes practically limitless number of tailorable covalent ${ }^{18}$ and non-covalent ${ }^{19}$ post-modifications, high surface area 
enabling homogeneous distribution of the nano-size actual catalysts, ${ }^{20}$ dedicated dispersibility in liquid and solid phase systems, ${ }^{21}$ convenient assembling in the macro-scale, ${ }^{22}$ high mechanical stability ${ }^{23}$ and excellent thermal conductivity, ${ }^{24}$ in addition to facile separation and recovery from the reaction mixture. Acid-functionalised CNTs have already been reported as efficient catalysts for the conversion of monosaccharides ${ }^{5}$ or furfuryl alcohol to LAEs..$^{9,10}$

SILP catalysts retain the important physical and chemical features of ILs, such as non-volatility, nonflammability and good thermal stability, while adding advantage in terms of catalyst recovery, regeneration and reuse..$^{25,26}$ Encouraged by our earlier work, ${ }^{20,27,28}$ we decided to non-covalently support trifloaluminate ionic liquids on commercially available, inexpensive multi-walled carbon nanotubes (MWCNTs). To the best of our knowledge, it is the first attempt to use any form of solid-immobilised metal triflate for the synthesis of LAEs.

Ionic liquid $\left[\mathrm{C}_{2} \mathrm{mim}\right][\mathrm{OTf}]-\mathrm{Al}(\mathrm{OTf})_{3}, \chi_{\mathrm{Al}(\mathrm{OTf}) 3}=0.25$, was immobilized on the commercially available CheapTubes $^{\mathrm{TM}}$ MWCNTs, at a mass ratio of MWCNTs to ionic liquid of 2:1 to yield the SILP catalyst, MWCNT- $\left[\mathrm{C}_{2} \mathrm{mim}\right][\mathrm{OTf}]-\mathrm{Al}(\mathrm{OTf})_{3}, \chi_{\mathrm{Al}(\mathrm{OTf}) 3}=0.25$. The quantity of the active phase (ionic liquid) was estimated by TGA to be at the level of $13.8 \mathrm{wt} \%$ (Figure S1-S5). Comparative characterisation of MWCNTs and the SILP catalyst is shown in Table 4. As expected, both the pore volume $\left(\mathrm{V}_{\mathrm{p}}\right)$ and the overall surface area $\left(\mathrm{S}_{\mathrm{BET}}\right)$ were lower for the SILP, when compared to neat MWCNTs, which most likely results from the ionic liquid occupying the interstitial MWCNT bundle channels - forming both pores and the available surface.

The quantity of SILP catalyst was calculate to ensure the loading of $0.009 \mathrm{~mol} \%$ of ionic liquid per $\alpha$ $\operatorname{AL}(0.13 \mathrm{~g}$ of the ionic liquid catalyst per $12.5 \mathrm{~g}$ of $\alpha-\mathrm{AL})$. Reaction of equimolar amount of reactants, carried out at $60{ }^{\circ} \mathrm{C}$, gave full conversion of $\alpha$-AL to $n$-butyl levulinate after $60 \mathrm{~min}$, with selectivity $>99 \%$, which was comparable to neat ionic liquid under the same conditions (see Table 2). Likewise, relatively high corresponding TON and TOF values $\left(5.9 * 10^{5}\right.$ and $9.8^{*} 10^{3}$, respectively) were achieved. 
Table 4. Characterisation of MWCNTs and MWCNT-[C $\left.\mathrm{C}_{2} \operatorname{mim}\right][\mathrm{OTf}]-\mathrm{Al}(\mathrm{OTf})_{3}, \chi_{\mathrm{Al}(\mathrm{OTf}) 3}=0.25$

\begin{tabular}{|c|c|c|c|c|c|c|}
\hline $\begin{array}{l}\text { Support/ } \\
\text { catalyst }\end{array}$ & $\begin{array}{l}\text { SBET, } \\
\mathrm{m}^{2} \mathrm{~g}^{-1}\end{array}$ & $\begin{array}{l}\mathrm{V}_{\mathrm{p}} \\
\mathrm{cm}^{3} \mathrm{~g}^{-1}\end{array}$ & $\begin{array}{l}\text { Length, } \\
\mu \mathrm{m}\end{array}$ & $\begin{array}{l}\text { Outer } \\
\text { diameter, } \\
\mathrm{nm}\end{array}$ & $\begin{array}{l}\text { Inner } \\
\text { diameter, } \\
\text { nm }\end{array}$ & $\begin{array}{l}\text { IL loading, } \\
\mathrm{wt}^{2} \%^{a}\end{array}$ \\
\hline $\begin{array}{l}\text { CheapTubes }^{\mathrm{TM}} \\
\text { MWCNTs }\end{array}$ & 89 & 0.49 & $10-30$ & $20-40$ & $5-10$ & - \\
\hline $\begin{array}{l}\text { MWCNT- } \\
{\left[\mathrm{C}_{2} \mathrm{mim}\right][\mathrm{OTf}]-} \\
\mathrm{Al}(\mathrm{OTf})_{3}, \chi_{\mathrm{Al}(\mathrm{OTf}) 3}=0.25\end{array}$ & 33 & 0.21 & $10-30$ & $>20-40$ & $5-10$ & 9.1 \\
\hline
\end{tabular}

${ }^{a}$ calculated based on TGA

To study recycling of the catalyst, after each catalytic run, the catalyst was filtered off, washed with $n$ hexane, subjected to vacuum to remove the solvent, and used for the next cycle. Catalyst recovery was highly efficient, at 96-99\%. Conversion and selectivity remained constant within the first five cycles, with a slight decline in the catalyst performance at the $6^{\text {th }}$ cycle (conversion $98 \%$, selectivity $94 \%$ ), as shown in Figure 2.

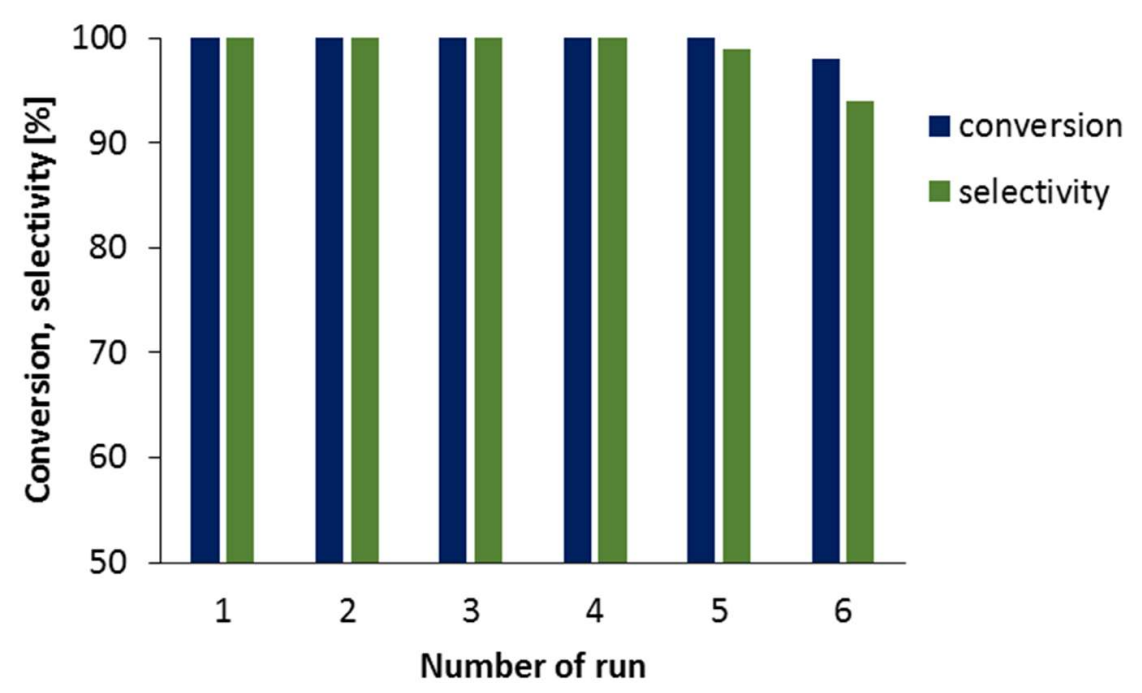

Figure 2. Conversions of $\alpha-\mathrm{AL}$ (navy) and selectivities to LAE (green), in a reaction catalysed by MWCNT- $\left[\mathrm{C}_{2} \mathrm{mim}\right][\mathrm{OTf}]-\mathrm{Al}(\mathrm{OTf})_{3}, \chi_{\mathrm{Al}(\mathrm{OTf}) 3}=0.25$, for consecutive recycles of the catalyst. Reaction conditions: $125 \mathrm{mmol} \alpha$-AL; molar ratio $\alpha$-AL:n-BuOH $1: 1 ; 60{ }^{\circ} \mathrm{C} ; 0.18$ g MWCNT-[C $\mathrm{C}_{2}$ mim][OTf]- 
$\mathrm{Al}(\mathrm{OTf})_{3}, \chi_{\mathrm{Al}(\mathrm{OTf}) 3}=0.25$; reaction time $60 \mathrm{~min}$; all experiments were performed in triplicate with results differing by less than $1 \%$; conversion and selectivity were determined using GC.

TGA studies (Figure S1-S5) of the catalyst after $1^{\text {st }}$ and $6^{\text {th }}$ cycle indicated the same amount of adsorbed ionic liquid as in the freshly prepared catalytic system (10.5 and $10.7 \mathrm{wt} . \%$, respectively, compared to 9.1 wt. $\%$ in the fresh material). The shape of the TGA curve recorded for the catalyst after the $6^{\text {th }}$ cycle suggests a small amount of co-adsorption of other components of the reaction mixture onto MWCNTs what resulted in a slight overestimation of the amount of immobilized ionic liquid (wt.\%) by TGA. Furthermore, this could result in the blockage of the catalyst pores, and be the source of observed decline in activity.

\section{Mechanistic considerations}

The mechanism of conversion of $\alpha$-AL to LAEs (Scheme 1), proposed by Al-Shaal et al., ${ }^{12}$ involves the protonation of $\alpha$-angelica and subsequent reaction with an alcohol, leading an intermediate, pseudolevulinic ester (pseudo-LAE). Subsequently, levulinic ester is obtained via acidic catalysis. Whereas conversion of $\alpha$-AL to pseudo-LAE is rather fast, the trans-esterification of pseudo-LAE to LAE is the rate-limiting step. Based on this mechanism, Al-Shaal et al. proposed that both conversion and selectivity are strongly dependent on the acidity of the catalyst, and high acidity is preferred.

Prior to this work, there have been only two literature reports concerning the conversion of $\alpha$-AL to $n$ butyl levulinate. When Amberlyst 36 was used as the catalyst (250 mg for $51 \mathrm{mmol}$ of $\alpha-A L)$, full conversion was reached after 240 min at $75{ }^{\circ} \mathrm{C}$, with selectivity to $n$-butyl levulinate at $94 \% .{ }^{12}$ Identified by-products included $1 \%$ of unreacted pseudo-n-butyl levulinic ester, and 5\% of LA. A series of cholineexchanged heteropolyacids ( $20 \mathrm{wt} \%$ to $\alpha$-angelica) gave full conversion after $60 \mathrm{~min}$ at $75{ }^{\circ} \mathrm{C}$, with selectivity to $n$-butyl levulinate at $79.4 \% .{ }^{13}$ Identified by-products included once again pseudo- $n$-butyl levulinic ester, and LA. 
Interestingly, in this work, the by-products detected after reactions catalysed with different metal triflate differed. When $\mathrm{La}(\mathrm{OTf})_{3}$ was used as the catalyst (conversion $94 \%$, selectivity $79 \%$ ), these included $3 \%$ of pseudo-n-alkyl levulinic ester, 7\% of levulinic acid and $11 \%$ of LAE hemi-acetal. In contrast, Al(OTf) 3 (conversion 94\%, selectivity 96\%) gave hemi-acetal of LAE as the only by-product (Scheme 1). Hemiacetal of LAE was also detected in traces as the only by-product in case of using neat (conversion 100\%, selectivity $>99 \%$ ) as well as immobilised ionic liquid (conversion $100 \%$, selectivity $>99 \%$ ) (Table 2 , Figure 2). The reason for this discrepancy may lie in water stability of different metal triflates. Whereas rare earth metal triflates, including $\mathrm{La}(\mathrm{OTf})_{3}$, are moisture-stable, $\mathrm{Al}(\mathrm{OTf})_{3}$ and $\mathrm{Ga}(\mathrm{OTf})_{3}$ and their ionic liquids were found to slowly hydrolyse in the presence of atmospheric moisture, releasing traces of triflic acid. ${ }^{14}$ It is the presence of highly Brønsted acidic protons next to Lewis acidic sites that seems to facilitate the conversion of $\alpha$-AL to LAE, and warrants exceptionally high selectivity.

\section{Conclusions}

In this work, a new heterogeneous acidic catalyst combining high activity and selectivity as well as the enhanced operational stability in the conversion of $\alpha$-angelica to LAEs was presented. Screening of Lewis acidic metal triflates yielding trifloaluminate ionic liquids as water tolerable unique Lewis acids brought to elaboration and development of the high-performance supported ionic liquid phase catalysts with CNTs as an effective currier. In conclusion, compared to the neat ionic liquid, the SILP system has fully retained the very attractive performance characteristics of the ionic liquid, but enhanced the recycling procedure. This method is proposed as a generic approach to tailoring ionic liquids as a replacement of hazardous acids in the industrially-relevant reactions. Heterogenisation of catalysts can offer advantages in handling, separation and recycling and may lead to both environmentally and economically sustainable processes. In order to translate these findings to an industrially viable proposition, the design of a continuous flow 
reactor for the synthesis of LAEs from biomass-based platform molecules is currently under investigation in our group.

\section{Supporting Information}

The following file is available free of charge: TGA curves (PDF)

Corresponding Authors

*anna.chrobok@polsl.pl

Author Contributions

The manuscript was written through contributions of all authors. All authors have given approval to the final version of the manuscript.

Funding Sources

This work was financed by the National Science Centre, Poland (grant no. UMO-2015/17/B/ST8/01422).

\section{References}

1. Pileidis, F. D.; Titirici, M. M. Levulinic Acid Biorefineries: New challenges for efficient utilization of biomass. ChemSusChem. 2016, 9, 562-582.

2. Melero, A.; Morales, G.; Iglesias, J.; Paniagua, M.; Hernández, B.; Penedo, S. Efficient conversion of levulinic acid into alkyl levulinates catalyzed by sulfonic mesostructured silicas. Appl. Catal. A: Gen. 2013, 466, 116-122.

3. Caretto, A.; Perosa, A. Upgrading of levulinic acid with dimethylcarbonate as solvent/reagent. ACS Sustain. Chem. Eng. 2013, 1, 989-994. 
4. Ding, D.; Xi, J.; Wang, J.; Liu, X.; Lu, G.; Wang, Y. Production of methyl levulinate from cellulose: selectivity and mechanism study. Green Chem. 2015, 17, 4037-4044.

5. Liu, R.; Chen, J.; Huang, X.; Chen, L.; Ma, L.; Li, X. Conversion of fructose into 5hydroxymethylfurfural and alkyl levulinates catalyzed by sulfonic acid-functionalized carbon materials. Green. Chem. 2013, 15, 2895-2903.

6. Kuo, C.-H.; Poyraz, A. S.; Jin, L.; Meng, Y.; Pahalagedara, L.; Chen, S.-Y.; Kriz, D. A.; Guild, C.; Gudz, A.; Suib, S. L. Heterogeneous acidic TiO2 nanoparticles for efficient conversion of biomass derived carbohydrates. Green Chem. 2014, 16, 785-791.

7. Song, D.; An, S.; Lu, B.; Guo, Y.; Leng, J. Arylsulfonic acid functionalized hollow mesoporous carbon spheres for efficient conversion of levulinic acid or furfuryl alcohol to ethyl levulinate. Appl. Catal. B: Environ. 2015, 179, 445-457.

8. Wang, G.; Zhang, Z.; Song, L. Efficient and selective alcoholysis of furfuryl alcohol to alkyl levulinates catalyzed by double $\mathrm{SO}_{3} \mathrm{H}$-functionalized ionic liquids. Green Chem. 2014, 16, 1436-1443.

9. Song, D.; An, S.; Sun, Y.; Guo, Y. Efficient conversion of levulinic acid or furfuryl alcohol into alkyl levulinates catalyzed by heteropoly acid and zro2 bifunctionalized organosilica nanotubes. J. Catal. 2016, 333, 184-199.

10. Song, D.; An, S.; Sun, Y.; Zhang, P.; Guo, Y.; Zhou, D. Ethane-bridged organosilica nanotubes functionalized with arenesulfonic acid and phenyl groups for the efficient conversion of levulinic acid or furfuryl alcohol to ethyl levulinate. ChemCatChem. 2016, 8, 2037-2048.

11. Lima, C. G. S.; Monteiro, J. L.; Lima, T. de M.; Paixão, M. W.; Corrêa, A. G. Angelica Lactones: From biomass-derived platform chemicals to value-added products. ChemSusChem. 2018, 11, 25-47. 12. Al-Shaal, M. G.; Ciptonugroho, W.; Holzhäuser, F. J.; Mensah, J. B.; Hausoul, P. J. C.; Palkovits, R. Catalytic upgrading of $\alpha$-angelica lactone to levulinic acid esters under mild conditions over heterogeneous catalysts. Catal. Sci. Technol. 2015, 5, 5168-5173. 
13. Yi, X.; Al-Shaal, M. G.; Ciptonugroho, W.; Delidovich, I.; Wang, X.; Palkovits, R. Synthesis of butyl levulinate based on $\alpha$-angelica lactone in the presence of easily separable heteropoly acid catalysts. ChemSusChem. 2017, 10, 1494-1500.

14. Latos, P.; Culkin, A.; Barteczko, N.; Boncel, S.; Jurczyk, S.; Brown, L. C.; Nockemann, P.; Chrobok, A.; Swadźba-Kwaśny, M. Water-tolerant trifloaluminate ionic liquids: new and unique Lewis acidic catalysts for the synthesis of chromane. Front. Chem. 2018, 6, 535.

15. Estager, J.; Holbrey, J.; Swadźba-Kwaśny, M. Halometallate ionic liquids - revisited. Chem. Soc. Rev. 2014, 43, 847-886.

16. Estager, J.; Oliferenko, A. A.; Seddon, K. R.; Swadźba-Kwaśny, M. Chlorometallate(III) ionic liquids as Lewis acidic catalysts-a quantitative study of acceptor properties. Dalton Trans. 2010, 39, 1137511382.

17. Yan, Y.; Miao, J.; Yang, Z.; Xiao, F.-X.; Yang, H. B.; Liu, B.; Yang, Y. Carbon nanotube catalysts: recent advances in synthesis, characterization and applications. Chem. Soc. Rev. 2015, 44, 3295-3346.

18. Zniszczoł, A.; Herman, A.; Szymańska, K.; Mrowiec-Bialon, J.; Walczak, K.; Jarzębski, A. B.; Boncel, S. Covalently immobilized lipase on aminoalkyl-, carboxy- and hydroxy-multi-wall carbon nanotubes in the enantioselective synthesis of Solketal esters. Enzyme Microb. Technol. 2016, 61, 87-88. 19. Boncel, S.; Zniszczoł, A.; Szymańska, K.; Mrowiec-Bialon, J.; Jarzębski, A. B.; Walczak, K. Alkaline lipase from Pseudomonas fluorescens non-covalently immobilised on pristine versus oxidised multi-wall carbon nanotubes as efficient and recyclable catalytic systems in the synthesis of Solketal esters. Enzyme Microb. Technol. 2013, 53, 263-270.

20. Markiton, M.; Szelwicka, A.; Boncel, S.; Jurczyk, S.; Chrobok, A. Superactive tin(II) triflate/carbon nanotube catalyst for the Baeyer-Villiger oxidation. Appl. Catal. A: Gen. 2018, 556, 81-91.

21. Herman, A. P.; Boncel, S. Nitrile N-oxides in programmable one-pot functionalization of multi-wall carbon nanotubes via 1,3-dipolar cycloaddition. RSC Adv. 2016, 6, 64129-64132. 
22. Koziol, K.; Boncel, S.; Shaffer, M. S. P.; Windle, A. Aligned carbon nanotube-polystyrene composites prepared by in situ polymerization of stacked layers. Compos. Sci. Technol. 2011, 71, 16061611.

23. Yu, M. F.; Lourie, O.; Dyer, M. J.; Moloni, K.; Kelly, T. F.; Ruoff, R. S. Strength and breaking mechanism of multiwalled carbon nanotubes under tensile load. Science 2000, 287, 637-640.

24. Boncel, S.; Zniszczoł, A.; Pawlyta, M.; Labisz, K.; Dzido, G. Heat transfer nanofluid based on curly ultra-long multi-wall carbon nanotubes. Heat Mass Transfer 2018, 54, 333-339.

25. Riisager, A.; Fehrmann, R.; Haumann, M.; Wasserscheid, P. Supported ionic liquid phase (silp) catalysis: an innovative concept for homogeneous catalysis in continuous fixed-bed reactors, Eur. $J$. Inorg. Chem. 2006, 4, 695-706.

26. Haumann, M.; Wasserscheid, P. SILP and SCILL Catalysis. In Catalysis in Ionic Liquids: From Catalyst Synthesis to Application, Hardacre, C.; Parvulescu, V., Eds.; Royal Society of Chemistry: Cambridge, 2014; Vol. 7, pp 410-432.

27. Mika, L. T.; Csefalvay, E.; Nemeth, A. Catalytic conversion of carbohydrates to initial platform chemicals: chemistry and sustainability. Chem. Rev. 2018, 118, 505-613.

28. Markiton, M.; Boncel, S.; Janas, D.; Chrobok, A. Highly active nanobiocatalyst from lipase noncovalently immobilized on multiwalled carbon nanotubes for Baeyer-Villiger synthesis of lactones. ACS Sustain. Chem. Eng. 2017, 8, 1685-1691. 
SYNOPSIS TOC: Highly selective ( $>99 \%)$ and reusable catalyst for the conversion of biobased platform molecule $\alpha$-angelica lactone to alkyl levulinates was presented.

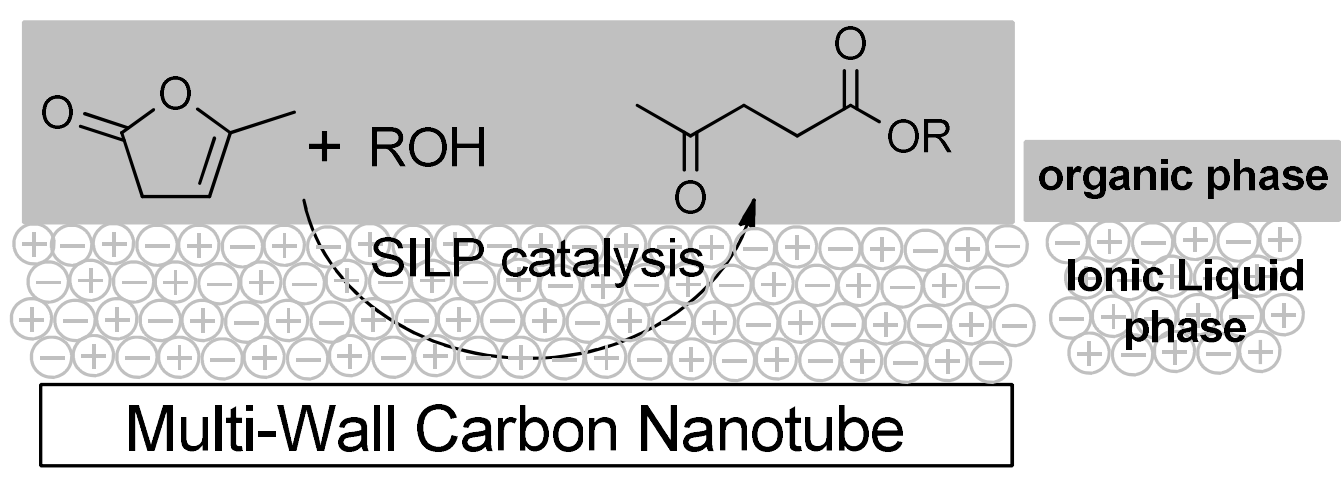

